\title{
The Gap in Economic Growth from Foreign Investment and Domestic Investment across Provinces in Indonesia
}

\author{
Asnawi ${ }^{1 *}, \operatorname{Irfan}^{1}$ and M. Fathul Chairi Ramadhani ${ }^{1}$ \\ ${ }^{1}$ Department of Economic Development, Universitas Malikussaleh, Aceh Utara, Indonesia \\ *Corresponding Author: asnawi.fe@unimal.ac.id
}

(Received 16 July 2020; Revised 28 July 2020; Accepted 24 August 2020)

\begin{abstract}
The study aims to determine the effect of Foreign Investment (FDI) and Domestic Investment (PMDN) on Cross-Province Economic Growth in Indonesia in 2014-2018. This study uses secondary data with Panel and Poled data consisting of 34 provinces in Indonesia, and use the 5 years time-series data during 2014-2018. The analytical method used is the panel regression analysis method with the Fixed Effect model and poled model. The results showed that foreign investment and domestic investment had a positive and significant effect on economic growth across provinces in Indonesia. Furthermore, the results of the study show that foreign investment and domestic investment have a significant and positive effect on economic growth in 8 provinces in Indonesia, and the foreign investment has a significant and positive influence on economic growth in 9 Provinces in Indonesia. However, only North Maluku, where foreign investment has a significant and negative effect on economic growth, and domestic investment significantly and positively affects economic growth in 6 provinces in Indonesia.
\end{abstract}

Key Words: Foreign Investment, Domestic Investment, Economic Growth

\section{INTRODUCTION}

Increased economic growth is an indicator of successful development in Indonesia, with the development of productive businesses in the real sector, thus creating jobs and increasing people's income. Efforts to accelerate the development of the real sector are by encouraging investment growth, both domestic investment (PMDN) and foreign investment (FDI). (Iamsiraroj \& Doucouliagos, 2015) reinforces the positive influence of FDI in the economic growth process for selected developing countries. Investment can contribute to various real sector developments in Indonesia. According to the Investment Coordinating Board (2018), there are 3 business sectors with the largest amount of investment, namely transportation, telecommunications and construction, industry, and the food sector.

The turmoil of world economic development, the escalating trade war between the United States and China as well as an error in the investment licensing mechanism carried out by the government, this has an impact on the growth of foreign investment in Indonesia, according to the Investment Coordinating Board (BKPM) (2018). \$2,932 million in 2018 was the largest amount for the past 5 years. However, the opposite occurred in domestic investment in Indonesia according to the Investment Coordinating Board (2018), it was noted that in 2018, it amounted to Rp.66,254 billion, with an increase of $25.32 \%$ from 2017. The increase in domestic investment was caused by a weakening of the purchasing power of money. rupiah, high domestic currency circulation, and most economic actors divert their business activities domestically.

According to the Investment Coordinating Board (2018), it is seen that the overall foreign investment (FDI) is larger, namely $62.9 \%$ in 2017, with domestic investment only 37.9\%. Meanwhile, in 2018 the amount of foreign investment was $54.5 \%$, with domestic investment amounting to $45.6 \%$. The spread of foreign investment and domestic investment to 34 provinces in Indonesia, however, there is a striking difference that there is an inequality in the distribution of investment, wherein DKI Jakarta, West Java, Central Java, East Java, and East Kalimantan, investment has increased, by 56.2\% (2018) ), while in other areas, namely the island of Sumatra, parts of Kalimantan, Sulawesi and Papua, the investment amount is smaller, amounting to 43.8\% (Investment Coordinating Board, 2018), this also has an impact on uneven economic growth.

\section{LITERATURE REVIEW}

The aim of increasing foreign investment and domestic investment in Indonesia is to increase real sector growth, increase production, create jobs, and increase national output which has an impact on increasing economic growth as the goal of economic development. (Arsyad, 2010) states that the factors that can affect economic growth consist of; (1) capital 
accumulation, in which economic growth occurs with an increase in investment; (2) population growth that can increase the number of workers; and (3) technological advances that can increase the mobility and skills of labor, as well as production factors in increasing yields. Meanwhile, Nurske said that poverty in developing countries can be stopped by increasing capital, with additional capital, the availability of tools and machines will increase production and ultimately increase national income from the increased output produced (Jhingan, 2016).

Harrod-Domar assumes that the development process is a matter of increasing capital investment, with the problem of underdevelopment is a problem of lack of capital and if the capital is available and the capital is invested, growth will occur (Zakaria, 2009). (Law Number 25 of 2007) states that Foreign Investment is an investment activity to conduct business in the territory of the Republic of Indonesia which is carried out by foreign investors, either using foreign capital fully or in partnership with domestic investors. Foreign investors are individuals who are foreign citizens, foreign business entities, or foreign governments investing in the territory of the Republic of Indonesia.

The results of the study (Hussain \& Haque, 2016) found that trade and FDI have a significant impact on the economic performance of Bangladesh. This study also shows a long-term relationship between the variables used in the model. The study concludes by recommending that the Mauritanian government should implement policies that have the potential to make the country's macroeconomic environment competitive and thus encourage FDI.

(Onakoya, 2012) By using a disaggregated dataset using a structural macro-econometric model consisting of four blocks, namely; supply, private demand, government, and the external sector to measure the impact of FDI on economic growth. The findings indicate that FDI contributes to the promotion of economic growth in Nigeria. However, the effects of FDI growth vary across sectors.

(Bakari, 2017b) The results determine that there is a positive impact of domestic investment, exports, and labor on economic growth in the long run; however, there is no relationship between domestic investment and economic growth in the short term (Bakari, 2018). The empirical results show that in the long term carrying out domestic investment hurts economic growth; However, exports and imports have a positive effect on economic growth. In the short term, only domestic investment and imports lead to economic growth in Algeria.

\section{Research Purposes}

The research objective is to determine the effect of foreign investment and domestic investment on economic growth across provinces in Indonesia in 2014-2018.

\section{RESEARCH METHOD}

This study uses secondary data in the form of poled data which is sourced from the Investment Coordinating Board and the Central Bureau of Statistics for 5 years. The data analysis aims to simplify the data in a form that is easier to read to interpret. The data poled in this study have 3 methods to test the data, as follows:

Common Effect Model

$$
Y_{i t}=\beta_{0}+\beta_{1} X_{1 i t}+\beta_{2} X_{2 i t}+\mu_{i i t}
$$

Fixed Effect Model

$$
Y_{i t}=\beta_{0}+\beta_{1} X_{i t}+\beta_{2} W_{i t}+D_{2} Z_{i t}+\varepsilon_{i t}
$$

Random Effect Model

$$
Y_{i t}=\beta_{0}+B_{1} X_{1 i t}+\beta_{2} X_{2 i t}+e i t+\mu_{i i t}
$$

\section{Poled Model Regression Analysis}

a. Model 1 is the additive model with the equation:

$$
P D R B_{i t}=\beta_{0 i}+\beta_{1 i} F D I_{i t}+\beta_{2 i} P M D N_{i t}+\varepsilon_{i t}
$$

b. Model 2 is the sum model in 34 Provinces in Indonesia, with the following equation, for one of the Provinces to-j

$$
P D R B_{j . i t}=\beta_{j 0}+\beta_{j 1} * F D I+\beta_{j 2} * P M D N+\varepsilon_{i t}
$$

\section{Data and Sources}

The data used to assess the effect of foreign investment and domestic investment is the 2014-2018 panel data. Data on foreign investment and domestic investment are obtained from the Indonesian Investment Coordinating Board and data on the Gross Regional Domestic Product (GRDP) in provinces in Indonesia. 


\section{RESULTS AND DISCUSSION}

In the selection of polled data analysis with Chow test, Haustman test and LM test, which was selected in this study is the Fixed Effect Model. With the results and explanation of the polled data regression in table 1.

Table 1. Fixed Effect Model Regression Test Results

\begin{tabular}{ccccc}
\hline Variabel & Coefficient & Std. Error & t-Statistics & Prob. \\
\hline C & 11.30872 & 0.086156 & 131.2583 & 0.0000 \\
\hline LOG(FDI) & 0.033312 & 0.009834 & $3.387503^{* * *}$ & 0.0009 \\
\hline LOG(PMDN) & 0.034736 & 0.005066 & $6.856167 * * *$ & 0.0000 \\
\hline
\end{tabular}

\section{$* * *$ Significant $1 \%$}

The results of the study are based on table 1, that a constant of 11.30872 indicates that if FDI and PMDN are (constant), then the GRDP in Indonesia is also $11.30 \%$. The coefficient (FDI) has a value of 0.033 , this indicates a positive relationship. This means that if FDI increases by 1\%, then GRDP in Indonesia will also increase by $0.033 \%$. The variable coefficient $(\mathrm{PMDN})$ has a value of 0.034 . This indicates a positive relationship. This means that if PMDN increases by $1 \%$, then GRDP in Indonesia will also increase by $0.034 \%$. There are several reasons that explain the influence of foreign investment and domestic investment, where from several provinces it is caused by abundant natural resources, quality human resources, developing and progressing MSMEs and ease of licensing to do business.

Table 2. Results of the Poled Data Regression Test and the Fixed Effect Model

\begin{tabular}{|c|c|c|c|c|}
\hline Variabel & Coefficient & Std. Error & t-Statistic & Prob. \\
\hline $\mathrm{C}$ & 10.23675 & 0.109984 & 93.07484 & 0.0000 \\
\hline LOG(FDI_ACEH) & 0.132754 & 0.035844 & $3.703660 * * *$ & 0.0003 \\
\hline LOG(FDI_BALI) & 0.169877 & 0.052626 & $3.227990 * * *$ & 0.0017 \\
\hline LOG(FDI_BANTEN) & 0.006077 & 0.209981 & 0.028940 & 0.9770 \\
\hline LOG(FDI_BENGKULU) & 0.043377 & 0.027812 & 1.559667 & 0.1220 \\
\hline LOG(FDI_DIY) & 0.106634 & 0.037453 & $2.847149 * *$ & 0.0054 \\
\hline LOG(FDI_DKI) & 0.336637 & 0.075391 & $4.465199^{* * *}$ & 0.0000 \\
\hline LOG(FDI_GRNTLO) & -0.078434 & 0.052243 & -1.501324 & 0.1365 \\
\hline LOG(FDI_JABAR) & 0.100352 & 0.105313 & 0.952893 & 0.3430 \\
\hline LOG(FDI_JAMBI) & 0.170015 & 0.103054 & 1.649763 & 0.1022 \\
\hline LOG(FDI_JATENG) & 0.037783 & 0.073914 & 0.511172 & 0.6104 \\
\hline LOG(FDI_JATIM) & -0.033187 & 0.144149 & -0.230229 & 0.8184 \\
\hline LOG(FDI_KALBAR) & -0.006469 & 0.057900 & -0.111720 & 0.9113 \\
\hline LOG(FDI_KALSEL) & 0.036785 & 0.030596 & 1.202270 & 0.2321 \\
\hline LOG(FDI_KALTENG) & 0.048343 & 0.028854 & 1.675417 & 0.0970 \\
\hline LOG(FDI_KALTIM) & 0.115618 & 0.044655 & $2.589130 * *$ & 0.0111 \\
\hline LOG(FDI_KALUT) & 0.010659 & 0.053220 & 0.200290 & 0.8417 \\
\hline LOG(FDI_KBANGBIL) & -0.005496 & 0.044528 & -0.123420 & 0.9020 \\
\hline LOG(FDI_KRIAU) & 0.196363 & 0.023044 & $8.521347^{* * *}$ & 0.0000 \\
\hline LOG(FDI_LAMPUNG) & 0.139362 & 0.036961 & $3.770554^{* * * *}$ & 0.0003 \\
\hline LOG(FDI_MALUKU) & -0.011039 & 0.016922 & -0.652378 & 0.5157 \\
\hline LOG(FDI_MALUT) & -0.043045 & 0.017724 & $-2.428646^{* *}$ & 0.0170 \\
\hline LOG(FDI_NTB) & 0.069878 & 0.020249 & $3.450984^{* * * *}$ & 0.0008 \\
\hline LOG(FDI_NTT) & 0.126514 & 0.029479 & $4.291644^{* * *}$ & 0.0000 \\
\hline LOG(FDI_PABAR) & 0.069822 & 0.020474 & $3.410248^{* * * *}$ & 0.0009 \\
\hline LOG(FDI_PAPUA) & 0.188525 & 0.025854 & $7.291803^{* * *}$ & 0.0000 \\
\hline LOG(FDI_RIAU) & 0.129624 & 0.118900 & 1.090194 & 0.2783 \\
\hline LOG(FDI_SULBAR) & 0.004128 & 0.029237 & 0.141197 & 0.8880 \\
\hline LOG(FDI_SULSEL) & 0.225116 & 0.038724 & $5.813284^{* * *}$ & 0.0000 \\
\hline LOG(FDI_SULTENG) & 0.053334 & 0.019902 & $2.679747^{* *}$ & 0.0086 \\
\hline LOG(FDI_SULTENGG) & 0.124486 & 0.059692 & $2.085454^{*}$ & 0.0396 \\
\hline LOG(FDI_SULUT) & 0.122072 & 0.035076 & $3.480201^{* * *}$ & 0.0007 \\
\hline LOG(FDI_SUMBAR) & 0.145154 & 0.043182 & $3.361471^{* * *}$ & 0.0011 \\
\hline LOG(FDI_SUMSEL) & 0.165760 & 0.035830 & $4.626303^{* * *}$ & 0.0000 \\
\hline LOG(FDI_SUMUT) & 0.163350 & 0.104211 & 1.567495 & 0.1202 \\
\hline LOG(PMDN_ACEH) & 0.077018 & 0.030289 & $2.542727^{* *}$ & 0.0125 \\
\hline LOG(PMDN_BALI) & 0.009058 & 0.070009 & 0.129389 & 0.8973 \\
\hline LOG(PMDN_BANTEN) & 0.272482 & 0.232697 & 1.170974 & 0.2444 \\
\hline LOG(PMDN_BENGKULU) & 0.013028 & 0.021575 & 0.603874 & 0.5473 \\
\hline LOG(PMDN_DIY) & 0.065916 & 0.033478 & $1.968903^{*}$ & 0.0518 \\
\hline LOG(PMDN_DKI) & 0.032765 & 0.080505 & 0.406999 & 0.6849 \\
\hline LOG(PMDN_GRNTLO) & 0.042613 & 0.038243 & 1.114257 & 0.2679 \\
\hline LOG(PMDN_JABAR) & 0.261268 & 0.114484 & $2.282140^{* *}$ & 0.0246 \\
\hline LOG(PMDN_JAMBI) & 0.046174 & 0.090195 & 0.511931 & 0.6098 \\
\hline LOG(PMDN_JATENG) & 0.310029 & 0.074130 & $4.182246^{* * *}$ & 0.0001 \\
\hline LOG(PMDN_JATIM) & 0.402031 & 0.137831 & $2.916839 * *$ & 0.0044 \\
\hline LOG(PMDN_KALBAR) & 0.169113 & 0.060018 & $2.817702^{* *}$ & 0.0058 \\
\hline LOG(PMDN_KALSEL) & 0.134985 & 0.031195 & $4.327117 * * *$ & 0.0000 \\
\hline LOG(PMDN_KALTENG) & 0.081114 & 0.030404 & $2.667930^{* *}$ & 0.0089 \\
\hline
\end{tabular}




\begin{tabular}{|c|c|c|c|c|}
\hline LOG(PMDN_KALTIM) & 0.174891 & 0.046683 & $3.746394^{* * *}$ & 0.0003 \\
\hline LOG(PMDN_KALUT) & 0.076253 & 0.055357 & 1.377477 & 0.1715 \\
\hline LOG(PMDN_KBANGBIL) & 0.079362 & 0.042014 & 1.888921 & 0.0618 \\
\hline LOG(PMDN_KRIAU) & -0.005213 & 0.025538 & -0.204144 & 0.8387 \\
\hline LOG(PMDN_LAMPUNG) & 0.114479 & 0.032012 & $3.576107 * * *$ & 0.0005 \\
\hline LOG(PMDN_MALUKU) & 0.016128 & 0.019498 & 0.827128 & 0.4102 \\
\hline LOG(PMDN_MALUT) & 0.020488 & 0.017481 & 1.172023 & 0.2440 \\
\hline LOG(PMDN_NTB) & 0.078854 & 0.021487 & $3.669749 * * *$ & 0.0004 \\
\hline LOG(PMDN_NTT) & -0.014857 & 0.021094 & -0.704312 & 0.4829 \\
\hline LOG(PMDN_PABAR) & 0.030248 & 0.037120 & 0.814876 & 0.4171 \\
\hline LOG(PMDN_PAPUA) & -0.037132 & 0.037335 & -0.994542 & 0.3224 \\
\hline LOG(PMDN_RIAU) & 0.173801 & 0.124377 & 1.397364 & 0.1654 \\
\hline LOG(PMDN_SULBAR) & -0.004386 & 0.022479 & -0.195094 & 0.8457 \\
\hline LOG(PMDN_SULSEL) & 0.039740 & 0.040026 & 0.992853 & 0.3232 \\
\hline LOG(PMDN_SULTENG) & 0.090967 & 0.023155 & $3.928691 * * *$ & 0.0002 \\
\hline LOG(PMDN_SULTENGG) & -0.003040 & 0.068422 & -0.044436 & 0.9646 \\
\hline LOG(PMDN_SULUT) & 0.001380 & 0.034012 & 0.040570 & 0.9677 \\
\hline LOG(PMDN_SUMBAR) & 0.082285 & 0.041959 & $1.961048^{*}$ & 0.0527 \\
\hline LOG(PMDN_SUMSEL) & 0.068538 & 0.035267 & $1.943429^{*}$ & 0.0548 \\
\hline LOG(PMDN_SUMUT) & 0.142905 & 0.113987 & 1.253694 & 0.2129 \\
\hline R-squared & 0.996978 & \multicolumn{2}{|c|}{ Mean dependent var } & 11.85301 \\
\hline Adjusted R-squared & 0.994903 & \multicolumn{2}{|c|}{ S.D. dependent var } & 1.142431 \\
\hline S.E. of regression & 0.081565 & \multicolumn{2}{|c|}{ Akaike info criterion } & -1.882249 \\
\hline Sum squared resid & 0.658632 & \multicolumn{2}{|c|}{ Schwarz criterion } & -0.599193 \\
\hline Log likelihood & 227.1089 & \multicolumn{2}{|c|}{ Hannan-Quinn criter. } & -1.361522 \\
\hline F-statistic & 480.3365 & \multicolumn{2}{|c|}{ Durbin-Watson stat } & 1.976642 \\
\hline Prob(F-statistic) & 0.000000 & & & \\
\hline
\end{tabular}

*** Significant at $1 \%, * *$ Significant at $5 \%, *$ Significant at $1 \%$.

The results of the study based on table 2 were obtained, namely 8 provinces in Indonesia, namely the province of Aceh, DIY. Yogyakarta, East Kalimantan, Lampung, West Nusa Tenggara, Central Sulawesi, West Sumatra and South Sumatra foreign investment and domestic investment have a significant and positive impact on economic growth, indicating that the licensing bureaucracy for investment in these 8 provinces has been conducive and conditions productive economy, to encourage foreign investment and domestic investment. Furthermore, 9 provinces in Indonesia, namely the province of Bali, DKI Jakarta, Riau Islands, East Nusa Tenggara, West Papua, Papua, South Sulawesi, Southeast Sulawesi and North Sulawesi with significant foreign investment have a positive effect on economic growth, this means that natural resources are abundant in the province, which encourages foreign investment to do business and the local governments in the 9 provinces provide adequate bureaucratic permits. However, there is 1 province in Indonesia, which is North Maluku province, where foreign investment has a significant and negative effect on economic growth. This shows that foreign investment in the province has an impact on declining economic growth, due to the safety factor of investment that is not conducive so that investors lose.

Furthermore, according to table 2, it is explained that there are 6 provinces (West Java, Central Java, East Java, West Kalimantan, South Kalimantan, and Central Kalimantan) in Indonesia with significant domestic investment and positively affecting economic growth, this shows that domestic investment is sufficient. developing in small and medium enterprises (UMKM) in the province of West, Central, and East Java. Meanwhile, in the provinces of West, South, and Central Kalimantan, more domestic investment is in the oil and rubber plantation sector and the mining sector.

\section{CONCLUSION}

Based on the results showed that foreign investment and domestic investment had a positive and significant effect on economic growth across provinces in Indonesia. Furthermore, the results of the study show that foreign investment and domestic investment have a significant and positive effect on economic growth in 8 provinces in Indonesia, and the foreign investment has a significant and positive influence on economic growth in 9 Provinces in Indonesia. However, only North Maluku, where foreign investment has a significant and negative effect on economic growth, and domestic investment significantly and positively affects economic growth in 6 provinces in Indonesia

\section{REFERENCES}

Arsyad, L. (2010). Ekonomi Pembangunan. Yogyakarta: UPP STIE YKPN.

Badan Koordinasi Penanaman Modal (BKPM). Diunduh dari website www.bkpm.go.id (diakses pada November 2019)..

Bakari, S. (2017b). The Impact of Domestic Investment on Economic Growth: New Evidence from Malaysia. MPRA Paper No. 79436, (79436).

Bakari, S. (2018). The Impact of Domestic Investment on Economic Growth New Policy Analysis from Algeria. Ekonomik Teori ve Analiz Dergisi, 3(1), 35-51. https://doi.org/10.25229/beta.337367

Hussain, M., \& Haque, M. (2016). Foreign Direct Investment, Trade, and Economic Growth: An Empirical Analysis of Bangladesh. Economies, 4(4), 7. https://doi.org/10.3390/economies4020007 
Iamsiraroj, S., \& Doucouliagos, H. (2015). Does growth attract FDI? Economics, 9, 1-36. https://doi.org/10.5018/economics-ejournal.ja.2015-19

Jhingan, M. . (2016). Ekonomi Pembangunan dan Perencanaan (16th ed.). Jakarta: PT RajaGrafindo Persada.

Onakoya, A. B. (2012). Foreign Direct Investments and Economic Growth in Nigeria : A Disaggregated Sector Analysis. $3(10), 66-75$.

Undang-Undang Nomor 25 Tahun 2007. (N.D.).

Zakaria, J. (2009). Pengantar Teori Ekonomi Makro. Gaung Persada Perss. 